\title{
Peering into the Campaign Finance Law Crystal Ball: Guiding Principles for the Future of the BCRA and "Issue Advocacy" in Citizens United and Beyond*
}

\section{INTRODUCTION}

As though he were predicting, and perhaps inviting, a challenge in the near future, Justice Alito wrote just two years ago in FEC $v$. Wisconsin Right to Life, Inc. (WRTL II), that "[i]f it turns out that the implementation of the as-applied standard set out in the principal opinion impermissibly chills political speech, we will presumably be asked in a future case to reconsider the holding in McConnell $v$. [FEC] that $\S 203$ [of the Bipartisan Campaign Reform Act of 2002 (BCRA)] is facially constitutional." "Thanks to maneuvering by the Supreme Court of the United States, that future case is now at hand and a majority of the Justices appear poised to dramatically rewrite campaign finance law as the Court reconsiders Citizens United v. FEC. ${ }^{2}$ Accordingly, this Comment develops - using insight from Justices who have emphasized First Amendment concerns in campaign finance jurisprudence-guiding principles for reaching a healthy democratic balance that fully protects pure issue advocacy while regulating sham issue advocacy under the BCRA. $^{3}$

* Mark A. Samsel. J.D. candidate 2010, University of Kansas School of Law. B.S. 2007, Missouri Valley College; Marshall, Missouri. I would especially like to extend my gratitude to Professor Richard Levy for his unyielding guidance. I would also like to acknowledge Professor Stephen McAllister, Anne Gepford Smith, Luke Wohlford, Tim Davis, Andrea Morrow, and the Kansas Law Review staff for their skill and assistance. Finally, I would like to thank the many individuals back home in the Wellsville, Kansas school district and at Valley who helped me develop the skills to write my first publication.

1. FEC v. Wis. Right to Life, Inc. (WRTL II), 551 U.S. 449, 482-83 (2007) (Alito, J., concurring) (citations omitted).

2. See Citizens United v. FEC, 129 S. Ct. 2893, 2893 (2009) (mem.) (directing the parties to file supplemental briefs addressing whether BCRA $\S 203$ is constitutional on its face and setting oral argument for September 9, 2009).

3. Bipartisan Campaign Reform Act of 2002, Pub. L. No. 107-155, 116 Stat. 81 (codified in scattered sections of $2,18,28,36$, and 47 U.S.C.). 
Campaign finance law has always moved in fits and turns as Congress and the courts have tried to balance multiple competing interests and values, but since the passage of the BCRA, this area of law has changed particularly fast, with even starker disagreement on the Court. As the Court reconsiders Citizens United, it can send the future of campaign finance law in a wide array of directions. Among its many options, the Court could reaffirm McConnell's holding, which upheld the facial validity of BCRA $\S 203$, while shoring up the test it developed in WRTL II for as-applied challenges. ${ }^{4}$ Perhaps a better alternative, the Court could strike down the BCRA's primary definition of "electioneering communication" as facially unconstitutional and implement the fallback definition provided in BCRA $\S 201$. To avoid vagueness concerns, this definition would likely require guiding principles with clear criteria for applying the standard in as-applied challenges. Finally, the Court could invalidate BCRA $\S 203$ in its entirety, which would raise the question of whether "electioneering communication," as used in the disclosure context of BCRA $\S 201$, also violates the U.S. Constitution, either on its face or as applied in certain situations.

Given the great uncertainty in this area of law and the wide array of directions in which the Court may go in Citizens United, writing this Comment presents both a challenge and a unique opportunity. By using clues from recent Supreme Court cases, this Comment seeks to advance campaign finance jurisprudence by developing solid legal premises that ensure that individuals, corporations, and unions may engage in political and electoral advocacy under a fair set of rules while closing the loophole for sham issue advocacy as the BCRA intended.

Peering into the crystal ball, it appears that the Court will use Citizens United to make substantial changes to campaign finance law and likely attempt to reconcile McConnell and WRTL II. ${ }^{5}$ Additionally, while

4. The WRTL II principal opinion developed a test that met widespread disapproval, even on the Court, as seven Justices criticized it. Many have expressed views that range from a characterization of mere incoherence to complete disapproval. See, e.g., Richard L. Hasen, Beyond Incoherence: The Roberts Court's Deregulatory Turn in FEC v. Wisconsin Right to Life, 92 MINN. L. REV. 1064, 1065 (2008) (stating that "as a matter of jurisprudence, the Roberts Court's new approach to campaign finance regulation is just as incoherent as the prior... approach, though moving in a decidedly different ideological direction"); The Supreme Court, 2006 Term-Leading Cases, 121 HARV. L. REV. 285, 292, 294 (2007) (asserting that "the new test is misguided for several reasons" and that "Chief Justice Roberts managed to have his cake and eat it, too").

5. See Adam Cohen, Editorial, A Century-Old Principle: Keep Corporate Money out of Elections, N.Y. TIMES, Aug. 11, 2009, at A16 (suggesting that "[t]he [C]ourt has gone to extraordinary lengths to hear the case"); Adam Liptak, Case Could Overhaul Rules on Campaign Spending, N.Y. TIMES, June 30, 2009, at A12 (explaining how the relatively rare action by the Court 
newly confirmed Justice Sotomayor is largely expected to champion deference to congressional acts in this area (like her predecessor Justice Souter), most believe that the Court as a whole will continue its recent swing to a deregulatory position and invalidate campaign restrictions on First Amendment grounds. ${ }^{6}$ Under these assumptions, it appears the question is not whether the Roberts Court will deregulate parts of campaign finance law, but rather how far it will go in undoing the BCRA and perhaps other existing law. As this Comment explores, it appears the best solution for the Court in Citizens United may be to overrule McConnell, strike down the BCRA's primary definition of electioneering communication as used in BCRA $\S 203$, and implement the fallback definition provided in BCRA $\S 201$ with a few guiding principles.

To begin with, it may help to identify a few basic premises on which both sides of the debate should agree. First, pure issue advocacy, as distinguished from genuine issue advocacy and issue advocacy generally, ${ }^{7}$ should not be regulated in our democratic form of government. To the extent that "electioneering communication" under BCRA $\S 203$ prohibits pure issue advocacy, the Court's overbreadth concerns are justified. Second, a set of rules must be established under which individuals, corporations, and unions can fairly participate in the American democracy. These campaign finance laws must be clear, stable, and predictable, as the rule of law requires, and reflect a number of competing constitutional values, such as First Amendment freedoms, the integrity of the electoral process, and public faith in democracy. ${ }^{8}$ Finally, while reasonable persons may disagree about whether Buckley $v$. Valeo's magic words standard ${ }^{9}$ regulates too much, not enough, or is about right, it is clear that organizations are able to engage in "bad sportsmanship" under the test - at least breaking the spirit of the law-by eschewing magic words to avoid regulation and airing advertisements that advocate for or against a candidate under the guise of issue advocacy. Rule of law and fairness demand, regardless of whether these organizations can ultimately engage in this form of electoral advocacy,

to set the case for reargument, rather than ruling for Citizens United on narrow grounds, suggests that the Court is considering a sweeping change to current law).

6. See, e.g., Adam Liptak, The Roberts Court, Tipped by Kennedy, N.Y. TIMES, July 1, 2009, at A1 (suggesting that Chief Justice Roberts has helped move Justice Kennedy and the Court to the right).

7. See infra Part III.C.1.a.

8. See Richard Briffault, WRTL II: The Sharpest Turn in Campaign Finance's Long and Winding Road, 1 ALB. Gov'T L. REV. 101, 127, 140 (2008) (explaining that campaign finance laws, while at times "speech-impairing," are also "democracy-promoting").

9. See infra Parts II.A-B. 
that this loophole be closed and replaced with a standard that enables organizations to exercise the full extent of their constitutional rightswhatever they may be - in good faith, rather than under a cloud of deceit.

Under these premises, this Comment proceeds to explore areas that may be helpful in moving forward with Citizens United and future campaign finance law. First, Part II summarizes campaign finance law from its earliest beginnings, through Buckley's magic words, to the "electioneering communication" standard of the BCRA. Next, Part III analyzes the two major cases following the enactment of the BCRA, which culminate in the current standard for the "functional equivalent of express advocacy." In doing so, this Comment examines areas in which the nine Justices may be able to reach middle ground as the Court attempts to reconcile McConnell and WRTL II in Citizens United and possibly later cases. Next, Part III.C.1 distinguishes, in clear and distinct terms, the three types of advocacy: pure issue advocacy, express candidate advocacy, and the functional equivalent of express advocacy, or mixed (so-called issue) advocacy. With the parameters of advocacy clearly defined, Part III.C. 2 determines when a so-called issue ad crosses the line to become the functional equivalent of express advocacy by promoting, attacking, supporting, or opposing a candidate. Next, Part III.C.3 examines where previous tests have gone awry to develop a constitutional standard to regulate mixed advocacy while protecting pure issue advocacy. Finally, Part III.C.4 asserts that if the Court overrules McConnell and holds BCRA $\S 203$ facially unconstitutional, the broader BCRA definition of "electioneering communication" should nevertheless continue to be used in the context of requiring increased disclosure under BCRA $\S 201$. Part IV concludes by applying the guiding principles developed throughout this Comment to the ads in both WRTL II and Citizens United and by peering into the campaign finance law crystal ball to analyze how the proposed standard may fare in the future.

\section{BACKGROUND}

Understanding campaign finance law is no easy task; it involves constitutional law, federal statutes, and a hodgepodge of Supreme Court precedent "marked by fine distinctions, uneasily consistent rulings, and cases pointing in different directions." 10 Before reaching the modern framework of campaign finance law, this Part examines the historical

10. Briffault, supra note 8 , at 140 . 
context by which the current predicament has evolved over the last century.

\section{A. The Beginning: The FECA and Buckley "Balancing Act" to Fight Perceived Corruption}

Throughout American history, the ever-evolving moneyed interests have invariably found ways to express their speech-contributing to political campaigns, in one form or another-perhaps earning the widespread perception that big money corrupts the American political process. At its most fundamental level, campaign finance law combats political corruption and the appearance thereof; a fight to prevent the privileged, wealthy elite from buying access, influence, and perhaps even votes, that impair the public good, the less fortunate, and our democratic values. It also reflects a basic struggle to preserve our most sacred rights as laid out in the First Amendment: "Congress shall make no law ... abridging the freedom of speech, or of the press; or the right of the people peaceably to assemble, and to petition the Government for a redress of grievances." $" 1$

Despite these revered values in our Bill of Rights, they soon grew in tension with the American political system. As early as 1905, President Theodore Roosevelt called upon Congress to enact vigorous legislation to protect the integrity of federal elections and eradicate perceived political corruption; "he found "no enemy of free government more dangerous and none so insidious." "12 A battle was set that continues to this day: a "clash between the public's interest in limiting the sources and amounts of money spent on elections in order to prevent corruption or promote political equality and the burdens that such regulations place on First Amendment rights of free speech and association."13 Stated differently, the battle that began in the early twentieth century has evolved in stages: preventing corruption, preventing the appearance of corruption, and now, preventing the circumvention of measures enacted to prevent corruption and the appearance thereof. ${ }^{14}$

Responding to President Roosevelt's call for action, Congress enacted the Tillman Act in 1907 and followed with a series of legislation

11. U.S. CONST. amend. I.

12. FEC v. Wis. Right to Life, Inc. (WRTL II), 551 U.S. 449, 509 (2007) (Souter, J., dissenting) (quoting President Roosevelt, 39 CONG. REC. 17 (1904)).

13. Hasen, supra note 4, at 1067.

14. Michael A. Rosenhouse, Annotation, Validity, Construction, and Application of Campaign Finance Laws-Supreme Court Cases, 19 A.L.R. FED. 2d 1, at $\S 2$ (2007). 
through the 1960s that limited the disproportionate influence and access of deep pockets and special interests on federal elections, regulated the spending of federal office campaigns, and mandated public disclosure of campaign finances. ${ }^{15}$ Consolidating its earlier reform efforts, Congress enacted the Federal Election Campaign Act of 1971 (FECA). ${ }^{16}$ This comprehensive legislation required more stringent and periodic disclosures of contributions and expenditures for federal candidates, political parties, and political action committees (PACs). ${ }^{17}$ Additionally, later amendments either limited or entirely prohibited contributions by individual citizens, political parties, and PACs. ${ }^{18}$ Finally, FECA amendments established the Federal Election Commission (FEC) to interpret and enforce its provisions. ${ }^{19}$

Following FECA's passage, its regulations were quickly tested in the courts. In Buckley v. Valeo, ${ }^{20}$ the seminal case in campaign finance law, the Supreme Court addressed FECA's constitutionality and laid the legal foundation for constitutional challenges for years to come. Among the new legal distinctions that developed from Buckley, the Court differentiated "contributions" from "expenditures." 21 Contributions are payments made to or in connection with a federal officeholder, federal candidate, or federal election. ${ }^{22}$ Expenditures, on the other hand, consist of payments on behalf of a federal officeholder, federal candidate, or federal election, or payments by individuals independently to support or oppose federal candidates. ${ }^{23}$ Under Buckley and its progeny, the distinction is crucial: the Court found that limits on expenditures were subject to strict scrutiny because they directly infringed upon constitutional free speech rights; however, limits on contributions were subject only to lesser scrutiny because they merely "marginally" restricted First Amendment rights. ${ }^{24}$ Buckley's distinction between contributions and expenditures grew more important in later years as the Court had unintentionally set the ball rolling for a larger battle that

\footnotetext{
15. WRTL II, 551 U.S. at 509-12 (Souter, J., dissenting).

16. Federal Election Campaign Act of 1971, Pub. L. No. 92-225, 86 Stat. 3 (codified as amended at 2 U.S.C. $\S \S 431-57$ (2006))

17. Chip Nielsen \& Jason D. Kaune, Overview of Federal Campaign Finance: Contribution and Expenditure Limitations, in CORPORATE POLITICAL ACTIVITIES 2007: COMPLYING With CAMPAIGN FinANCE, LOBBYING \& ETHICS LAWS 17-18 (2007).

18. Id.

19. Id. at 17

20. 424 U.S. 1 (1976).

21. See Nielsen \& Kaune, supra note 17, at 17, 21-24, 30-31.

22. Id. at 17, 21-24.

23. Id. at $17,30-31$.

24. Hasen, supra note 4, at 1068.
} 
loomed in the near future: express candidate advocacy versus issue advocacy.

\section{B. From Buckley to the BCRA: The Emergence of Magic Words and Sham Issue Advocacy}

Since Buckley, the Supreme Court's campaign finance jurisprudence has moved in shifts between deference and deregulation, depending on the composition of its membership. ${ }^{25}$ Rarely moving without a substantial number of dissenters, and never formally overturning any of its campaign finance precedents, the majorities have either shown respectful deference to legislation regulating campaign finances or shown hostility to the same legislative efforts on First Amendment grounds. ${ }^{26}$ As will be analyzed later, the Court's pendulum swung to a deregulatory position between McConnell and WRTL II. ${ }^{27}$

Notwithstanding the Court's wavering deference, its reliance on distinguishing express candidate advocacy from issue advocacy has persisted. After Buckley,

[c]andidates and groups spending money on communications that expressly advocate the election or defeat of a clearly identified federal candidate would be subject to federal disclosure requirements, but individuals and groups engaged in other political advocacysubsequently referred to as "issue advocacy"-were not subject to disclosure. Subsequently, the Court applied the express advocacy/issue advocacy distinction in determining the scope of the longstanding ban on the use of corporate and union treasury funds in federal elections. ${ }^{28}$

To address constitutional vagueness concerns, the Buckley Court drew a bright line between express advocacy and issue advocacy. The Court ruled that FECA regulations could only restrict express advocacy, defined as "communications that in express terms advocate the election or defeat of a clearly identified candidate." 29 Such a narrow requirement led to a "magic words" test; express advocacy consisted only of communications that used definite words such as "'vote for,' 'elect,' 'support,' 'cast your ballot for,' 'Smith for Congress,' 'vote against,'

25. $I d$.

26. $I d$

27. See infra Part III.B.

28. Richard Briffault, WRTL and Randall: The Roberts Court and the Unsettling of Campaign Finance Law, 68 OHIO ST. L.J. 807, 811 (2007) (citing Buckley v. Valeo, 424 U.S. 1, 80 (1976); FEC v. Mass. Citizens for Life, 479 U.S. 238, 249 (1986)) (footnote omitted).

29. Hasen, supra note 4, at 1073 (citing Buckley v. Valeo, 424 U.S. 1, 44 (1976)). 
'defeat,' [or] 'reject.",30 Thus, communications lacking these express words, even if intended or likely to influence the outcome of an election, were left unregulated by Buckley's interpretation of FECA. ${ }^{31}$ Although referred to as "issue advocacy," these communications often focused primarily on the issue of electing or defeating a candidate. ${ }^{32}$ Corporate and union funds could be used, with little effort and clever language, to avoid FECA requirements and clearly advocate for or against a candidate. ${ }^{33}$

Within a few election cycles, determined moneyed interests exploited this "sham issue advocacy" loophole to preserve access and influence. The following ad, for example, purports to advocate for the issue of family values; however, as identified by the Court, it clearly advocates for the defeat of candidate Bill Yellowtail:

Who is Bill Yellowtail? He preaches family values but took a swing at his wife. And Yellowtail's response? He only slapped her. But "her nose was not broken." He talks law and order ... but is himself a convicted felon. And though he talks about protecting children, Yellowtail failed to make his own child support payments - then voted against child support enforcement. Call Bill Yellowtail. Tell him to support family values.

Sham issue advocacy, such as the Yellowtail ad, boomed in the 1990s, with spending reaching \$150 million in 1996 and more than $\$ 500$ million by $2000 .^{35}$ In an attempt to regulate sham issue advocacy and close the loophole left open by Buckley and later cases, Congress responded with the BCRA. ${ }^{36}$

\section{The BCRA: From Magic Words to Electioneering Communications}

Sponsored by Senators John McCain and Russ Feingold, the BCRA developed a new "electioneering communication" standard to regulate

\footnotetext{
30. Buckley v. Valeo, 424 U.S. 1, 44 n.52 (1976).

31. Hasen, supra note 4 , at 1073.

32. Id.

33. Id. at $1073-74$.

34. McConnell v. FEC, 540 U.S. 93, 193 n.78 (2003); James Bopp, Jr. \& Richard E. Coleson, Distinguishing "Genuine" from "Sham" in Grassroots Lobbying: Protecting the Right to Petition During Elections, 29 CAMPBELL L. REV. 353, 402 (2007).

35. Hasen, supra note 4, at 1073-74.

36. Bipartisan Campaign Reform Act of 2002, Pub. L. No. 107-155, 116 Stat. 81 (codified in scattered sections of 2, 18, 28, 36, and 47 U.S.C.); Hasen, supra note 4, at 1074.
} 
sham issue advocacy. ${ }^{37}$ The BCRA sought to move away from the inflexible and ineffective magic words test to more realistically separate candidate advocacy from issue advocacy. ${ }^{38}$ Under the BCRA, regulated candidate advocacy now included - in addition to words of express advocacy as developed by FECA and Buckley - a broader definition of electioneering communication: "any broadcast, cable, or satellite communication that refers to a candidate for federal office and that is aired within 30 days of a federal primary election or 60 days of a federal general election in the jurisdiction in which that candidate is running for office." 39 Additionally, BCRA $\S 201$ also provided a fallback definition if the primary definition was held constitutionally insufficient. ${ }^{40}$ Under BCRA $\S 203$, corporations and unions could not spend general treasury funds on electioneering communications, that is, broadcast advertisements that advocated or criticized a particular federal candidate by name. ${ }^{41}$ Rather, such activities could only be conducted by a segregated fund for political purposes, more commonly known as a political action committee (PAC). ${ }^{42}$ Applying electioneering communication in the disclosure context, BCRA $\S 201$ also required broader disclosure for ads that were not prohibited under BCRA $\S 203 .{ }^{43}$

Although the new BCRA standard solved the vagueness problem that plagued FECA because it could be applied easily without guesswork, it presented a different constitutional challenge-overbreadth. ${ }^{44}$ The electioneering communication standard could capture ads that truly advocated an issue (despite mentioning a federal candidate by name), rather than solely ads that advocated to affect the outcome of an election. ${ }^{45}$ For instance, a corporation or union that wished to promote a genuine issue, perhaps intervention in a labor dispute or trade agreement, would be prohibited from mentioning federal officeholders during the BCRA's restricted time periods. ${ }^{46}$

37. Hasen, supra note 4, at 1074.

38. See Jonathan S. Krasno \& Frank J. Sorauf, Evaluating the Bipartisan Campaign Reform Act (BCRA), 28 N.Y.U. REV. L. \& SOC. ChANGE 121, 160-61 (2003) ("Whatever its utility might once have been, [the magic words test] is now irrelevant to how political ads are designed.").

39. FEC v. Wis. Right to Life, Inc. (WRTL II), 551 U.S. 449, 457-58 (2007) (citing Bipartisan Campaign Reform Act $\S 201(\mathrm{f})(3)(A)$ (codified at 2 U.S.C. $§ 434(f)(3)(A)(2006)$ ). See also Hasen, supra note 4, at 1074; Krasno \& Sorauf, supra note 38, at 160-61.

40. See infra note 156 and accompanying text.

41. Hasen, supra note 4, at 1074-75.

42. Id. at 1074 .

43. See 2 U.S.C. $\S 434(f)(1)-(2)(2006)$.

44. Hasen, supra note 4, at 1075.

45. Id.

46. See id. 
Following the enactment of the BCRA, the fight moved to the courts as one side argued to uphold the new restrictions, protect the integrity of federal elections, and eradicate perceived political corruption. The other side fervently fought the new regulations as encroachments upon First Amendment rights. With the battle scene set, the Court would be called upon to crown new victors in McConnell and WRTL II.

\section{ANALYSIS}

In the short existence of the BCRA, the Supreme Court has already laid down two monumental cases setting, and resetting, the direction of America's campaign finance law. In 2003, the McConnell Court upheld BCRA $\S 203$, on a five-to-four vote, as constitutional against a facial overbreadth challenge. ${ }^{47}$ Then, after determining in WRTL $I$ that an asapplied challenge to BCRA $\S 203$ was permissible, ${ }^{48}$ the WRTL II Court, in 2007, developed a controversial new test that, while arguably overruling McConnell, certainly reversed the direction of campaign finance law. This Part proceeds to analyze the splintered opinions in McConnell and WRTL II in an effort to help improve campaign finance jurisprudence as the Court reconsiders Citizens United and future courts and Congresses seek to find an effective balance in the field over the next century.

\section{A. McConnell: Leaving the Door Open for Pure Issue Advocacy}

In its first major assessment of the BCRA, the Court in McConnell substantially affirmed its constitutionality. ${ }^{49}$ In rejecting the plaintiffs' argument that BCRA $\S 203$ was unconstitutionally overbroad because its definition of electioneering communication allegedly encompassed too many genuine issue ads, the Court held that "[t]his argument fails to the extent that the issue ads [during the restricted periods] are the functional equivalent of express advocacy." 50 The "justifications for the regulation of express advocacy apply equally [to the issue ads] during those periods if the ads are intended to influence the voters' decisions and have that effect." ${ }^{, 51}$ While the precise percentage of issue ads that had an

47. McConnell v. FEC, 540 U.S. 93, 207 (2003).

48. Wis. Right to Life, Inc. v. FEC (WRTL I), 546 U.S. 410, 411-12 (2006).

49. Scot J. Zentner, Revisiting McConnell: Campaign Finance and the Problem of Democracy, 23 J.L. \& POL. 475, 475 (2007).

50. McConnell, 540 U.S. at 206.

51. Id. 
electioneering purpose was in dispute, "the vast majority of ads clearly had such a purpose." 52 The majority correctly stated that "future corporations and unions may finance genuine issue ads during [the restricted] timeframes by simply avoiding any specific reference to federal candidates, or in doubtful cases by paying for the ad from a segregated fund." 53 These alternatives, while reasonable, nevertheless raise overbreadth concerns, even if the vast majority of ads should be regulated.

In language that proved crucial in WRTL II, the McConnell majority "assume[d] that the interests that justify the regulation of campaign speech might not apply to the regulation of genuine issue ads." "54 These interests, of "the highest importance," included preserving the individual citizen's confidence in government, "preserving the integrity of the electoral process, preventing corruption, and sustaining the active, alert responsibility of the individual citizen in a democracy for the wise conduct of the government." 55

Although the BCRA passed the facial constitutional challenge in McConnell, it remained unclear whether BCRA $\S 203$ could be subjected to an as-applied challenge by a corporation or union in specific instances. ${ }^{56}$ The answer soon came as Wisconsin Right to Life, Inc., pushed the question by financing a so-called issue ad-one that mentioned a prohibited federal candidate-from its general treasury during the restricted period. ${ }^{57}$

\section{B. WRTL II: The Only "Majority" Opinion: "We Effectively Overruled McConnell”}

Before analyzing the splintered opinions in WRTL II, two important points should be made. First, the Court moved drastically from a deferential position (deferring to regulatory acts of Congress) to a deregulatory position (emphasizing First Amendment rights over the various interests that arguably justify campaign finance regulations). ${ }^{58}$ The swing, however, was not so much a change in ideology as a change

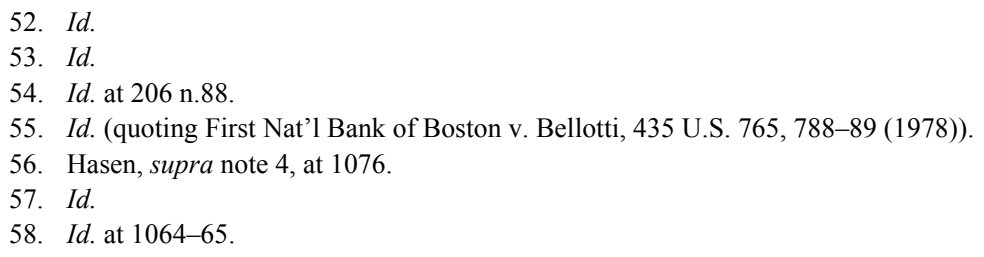


in the Court's membership. ${ }^{59}$ In the four years between McConnell and WRTL II, the seats of Chief Justice Rehnquist and Justice O'Connor were filled by Chief Justice Roberts and Justice Alito. ${ }^{60}$ The importance of this change cannot be overstated because the two newest members not only played a crucial role in reversing the direction of the Court's campaign finance jurisprudence in WRTL II, but they may also be the deciding votes in Citizens United.

Second, the Court's general tone toward campaign finance law also changed dramatically in WRTL II. McConnell was "full of language about legislative deference, flexibility, political reality, and the need to give Congress the room to address campaign finance problems step-bystep." It also traced congressional efforts to limit wealthy interests, noted the virtual ease of evading campaign finance laws, and minimized First Amendment concerns. ${ }^{62}$ The tone in WRTL II just four years later, on the other hand, runs to "the polar opposite of McConnell." ${ }^{\text {"63 }}$ Rather than speaking of PAC alternatives, congressional deference, or FECA loopholes, WRTL II assessed the BCRA in terms of a free speech "ban" or "blackout," censorship, and First Amendment rights. ${ }^{64}$ This turn to deregulation is expected to continue in Citizens United. ${ }^{65}$ With a basic understanding of the Court's changed membership and attitude following the McConnell decision, this Comment now analyzes each of the four opinions in WRTL II.

1. The Principal Opinion: Redefining the "Functional Equivalent of Express Advocacy"

While reflecting valid overbreadth concerns, the WRTL II principal opinion developed a test that met widespread disapproval on both sides of the issue and received the endorsement of only two Justices. ${ }^{66}$ Chief Justice Roberts began by examining the holding in McConnell, briefly noting the difference between campaign speech and "speech about public issues more generally" that mentions a federal candidate or officeholder. ${ }^{67}$ Critical to WRTL II's holding, he seized the language

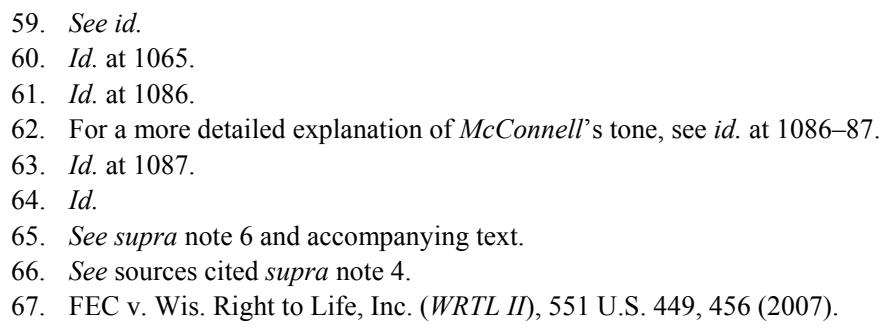


used in a footnote from McConnell's majority opinion: "the Court 'assumed' that the interests it had found to 'justify the regulation of campaign speech might not apply to the regulation of genuine issue ads." "68 It is worth pointing out, however, that the Court left the door open for genuine or pure issue ads, not the broader category of issue ads generally. ${ }^{69}$ This distinction is not consistently used in the Chief Justice's analysis: "the interests held to justify restricting corporate campaign speech or its functional equivalent do not justify restricting issue advocacy...." unnoticed $;{ }^{71}$ whether intentional or not, it drastically changes the result, for issue advocacy generally is comprised of two types: pure issue advocacy and mixed (so-called issue) advocacy. While McConnell left the door open for the former, it clearly upheld regulations on the latter. ${ }^{72}$ WRTL II's holding eliminated overbreadth concerns but presented vagueness issues and reopened the door for sham issue ads. ${ }^{73}$

The Chief Justice proceeded to reject the contention that McConnell had "already established the constitutional test for determining if an ad is the functional equivalent of express advocacy: whether the ad is intended to influence elections and has that effect." "74 Next, he developed his own test: "a court should find that an ad is the functional equivalent of express advocacy only if the ad is susceptible of no reasonable interpretation other than as an appeal to vote for or against a specific candidate." 75 The test is similar to the fallback definition of "electioneering communication" provided in BCRA $\S 201 .^{76}$ According to the Chief Justice's reasoning, ads that do not meet the definition of the functional equivalent of express advocacy in the test above fall outside the scope of McConnell's holding. ${ }^{77}$ Therefore, taking it a step further,

68. Id. (quoting McConnell v. FEC, 540 U.S. 93, 206 n.88 (2003)).

69. Although often used interchangeably, the differences between issue advocacy generally, genuine issue advocacy, and pure issue advocacy are analyzed infra at Part III.C.1.

70. WRTL II, 551 U.S. at 457.

71. The principal opinion surely recognizes the distinction, for it uses the term "genuine issue advocacy," rather than merely "issue advocacy," where it supports its contentions. See, e.g., id. at 470 ("Under [the WRTL II] test, WRTL's three ads are plainly not the functional equivalent of express advocacy. First, their content is consistent with that of a genuine issue ad ...." (emphasis added)).

72. McConnell v. FEC, 540 U.S. 93, 205, 206 n.88 (2003).

73. See WRTL II, 551 U.S. at 457.

74. Id. at 465 .

75. Id. at 469-70.

76. See infra note 156 and accompanying text.

77. WRTL II, 551 U.S. at 476. 
he reasoned that issue ads fall outside the scope of McConnell's holding and cannot be prohibited under BCRA $\S 203$. $^{78}$

Finally, the Chief Justice held that BCRA $\S 203$ was unconstitutional as applied to WRTL's ads because "[the ads were] not express advocacy or its functional equivalent, and because appellants identif[ied] no interest sufficiently compelling to justify burdening WRTL's speech ...."79 Among the justifications used by the Chief Justice, he cited the "liberty to discuss publicly and truthfully all matters of public concern," which necessitates an objective test that focuses on "the substance of the communication rather than amorphous considerations of intent and effect." ${ }^{\prime 1}$

In summary, the principal opinion reflects valid concerns that the standard under BCRA $\S 203$ could capture and prohibit pure issue advocacy. While pure issue advocacy can undoubtedly occur without mentioning a federal candidate, it is equally true that mentioning such a candidate does not automatically convert an otherwise pure issue ad into the functional equivalent of express advocacy, which the BCRA executed and McConnell approved. To the extent the principal opinion addressed these concerns, it should be commended. Nevertheless, to the much larger extent it permits a corporation to escape BCRA regulation merely because it can create an ad which contains a "reasonable" interpretation as something "other than [] an appeal to vote for or against a specific candidate, $" 82$ it should not be followed in Citizens United or later cases. The key is not whether an ad genuinely advocates for or against an issue, but rather, whether it reasonably can be interpreted as engaging - explicitly or implicitly - in any candidate advocacy. Thus, whereas an ad that genuinely advocates an issue and mentions a candidate should not necessarily be regulated, an ad that promotes or attacks a candidate, while perhaps also engaging in genuine issue advocacy, should always be regulated. For lack of a better term, it is the functional equivalent of express advocacy, which will be explored further in Part III.C.

\footnotetext{
78. Id. at 476-79.

79. Id. at 481 .

80. Id. at 469 (quoting First Nat'1 Bank of Boston v. Bellotti, 435 U.S. 765, 776 (1978)).

81. Id.

82. Id. at 470
} 


\section{Justice Alito's Concurring Opinion: If Necessary, Reconsider McConnell Later}

Justice Alito, the only other Justice to endorse the principal opinion's new test, wrote briefly in a concurring opinion apparently to explain his reluctance for not joining Justice Scalia's position that McConnell should be overruled and BCRA $\S 203$ declared facially unconstitutional. ${ }^{83}$ Rather than acknowledging that the principal opinion effectively overruled McConnell, as seven other Justices had done, Justice Alito took the middle ground, explaining that it was unnecessary to reconsider whether BCRA $\S 203$ was facially unconstitutional because the asapplied challenge resolved the issues in WRTL $I I^{84}$ Justice Alito subscribed to the principal opinion's belief that WRTL II merely resolved a gap left open by McConnell. ${ }^{85}$ As mentioned in Part I, the predictive language used by Justice Alito seems to illustrate even his doubts about the viability of the new test to which he subscribed, and possibly his openness to striking down BCRA $§ 203$ in Citizens United. ${ }^{86}$

\section{Building a Plurality Despite the Flawed Test: Overrule McConnell}

On the deregulatory side of the battle, Justices Scalia, Kennedy, and Thomas would have overruled the portion of McConnell that held BCRA $\S 203$ facially constitutional, thus negating the existence of as-applied challenges. ${ }^{87}$ Yet, the principal opinion was not ready to go that far and the Court was forced to articulate "the standard for prevailing in an asapplied challenge to BCRA $\S 203$." 88 Distancing his opinion from the Chief Justice's new test, Justice Scalia explained that no test "can both (1) comport with the requirement of clarity that unchilled freedom of political speech demands, and (2) be compatible with the facial validity of $\S 203$ (as pronounced in McConnell)." ${ }^{\prime 89}$ Rather, he wrote that any test, whether the principal opinion's test, the district court's five-part test, ${ }^{90}$ or otherwise, "is impermissibly vague and thus ineffective to vindicate the fundamental First Amendment rights of the large segment

\footnotetext{
83. See id. at 482 (Alito, J., concurring).

84. Id.

85. Id.

86. See id. at $482-83$.

87. Id. at $499-500$ (Scalia, J., concurring in part and concurring in the judgment).

88. Id. at 491

89. Id. at $483-84$.

90. See infra note 153 and accompanying text.
} 
of society to which [BCRA] $\S 203$ applies."91 Moreover, he explained that any such test sets the Court upon "the unsavory task of separating issue-speech from election-speech with no clear criterion." ${ }^{92}$ In Justice Scalia's belief, "[i]f a permissible test short of the magic-words test existed, Buckley would surely have adopted it."93

Yet, when Buckley was decided, it could not contemplate the explosion of sham issue advocacy leading up to the enactment of the BCRA. When the Court differentiated between express advocacy ${ }^{94}$ and the "narrow" exclusion of issue advocacy, ${ }^{95}$ it could not anticipate the colossal loophole that would develop and essentially remove any teeth from FECA regulations. Indeed, the Court would not realize the need to distinguish issue advocacy, as it defined it, from "genuine" or "pure" issue advocacy until years later. The Buckley Court did recognize, however, the need to prevent corruption and the appearance thereof, referring to "the 'quid pro quo' variety.","

Despite concurring in the judgment, Justice Scalia clearly took issue with the principal opinion's new test. ${ }^{97}$ Noting that the principal opinion's new test goes so far as to arguably protect even the most striking example of sham issue advocacy in the McConnell record, ${ }^{98}$ Justice Scalia gave a scathing review of the principal opinion's test and its proclaimed compatibility with McConnell:

[T] he principal opinion's attempt at distinguishing McConnell is unpersuasive enough, and the change in the law it works is substantial enough, that seven Justices of this Court, having widely divergent views concerning the constitutionality of the restrictions at issue, agree that the opinion effectively overrules McConnell without saying so. This faux judicial restraint is judicial obfuscation. ${ }^{99}$

\footnotetext{
91. WRTL II, 551 U.S. at 492 (Scalia, J., concurring in part and concurring in the judgment).

92. Id. at 484 .

93. Id. at 495 .

94. "[A]dvertising that 'in express terms advocates the election or defeat of a clearly identified candidate for federal office' by use of such words of advocacy 'as vote for, elect, support, ....'” Id. at 486-87 (quoting Buckley v. Valeo, 424 U.S. 1, 44 n.52 (1976)).

95. "[A]n ad that refers to a clearly identified candidate's position on an issue, but does not expressly advocate his election or defeat." Id. at 487.

96. Id. at 486 (citing Buckley v. Valeo, 424 U.S. 1, 26-27, 45, 47 (1976)).

97. See, e.g., id. at 496 ("Though the principal opinion purports to recognize the 'imperative for clarity' in this area of First Amendment law, its attempt to distinguish its test from the test found to be vague in Buckley falls far short."); id. at 499 n.6 ("The principal opinion claims that its test is no more vague than WRTL's test. I disagree." (citation omitted)).

98. See supra note 34 and accompanying text (examining the Yellowtail ad).

99. WRTL II, 551 U.S. at 499 n.7 (Scalia, J., concurring in part and concurring in the judgment) (citations omitted).
} 
Recognizing that any clever advocate could evade the regulations under FECA and Buckley's express advocacy standard, Justice Scalia nevertheless suggested that perhaps only two solutions consistent with the First Amendment exist: either restrictions on independent expenditures must be eliminated altogether or the restrictions must return to the traditional magic words standard of Buckley. ${ }^{100}$

Looking ahead to Citizens United, it is likely that Justices Scalia, Kennedy, and Thomas will continue to assert that BCRA $\S 203$, when using the primary definition of electioneering communication, is facially unconstitutional. However, they recognized the distinction between issue ads generally and "genuine" or "pure" issue ads. ${ }^{101}$ Thus, if clear criteria can be developed to separate "issue-speech" (pure issue advocacy) from "election-speech" (mixed advocacy), it is conceivable that these Justices may find more restrictive regulation constitutionally acceptable without the need to return to Buckley's magic words standard. $^{102}$ Part III.C.3 explores a standard that may have sufficiently clear criteria.

4. Justice Souter and the Dissent: WRTL II Stands McConnell on Its Head

Championing the position of legislative deference to congressional efforts to eradicate political corruption and the appearance thereof, and perhaps stare decisis to a lesser extent, the dissent, a vote short from its majority position in McConnell, maintained its tone and position as developed in that case. Justice Souter, joined by Justices Stevens, Ginsburg, and Breyer, explained the dissent's position in three points:

[(1)] the demand for campaign money in huge amounts from large contributors, whose power has produced a cynical electorate; [(2)] the congressional recognition of the ensuing threat to democratic integrity as reflected in a century of legislation restricting the electoral leverage of concentrations of money in corporate and union treasuries; and [(3)] McConnell [], declaring the facial validity of the most recent Act of Congress in that tradition, a decision that is effectively, and unjustifiably, overruled today.

100. Id. at 499 .

101. See id. at 485 .

102. See id. at 483-84.

103. Id. at 504 (Souter, J., dissenting). 
Devoting significant attention to the explosive growth and dangerous side effects of money spent on advertising, particularly for media time and space, the dissent recognized the need to implement the will of the people, as effected through congressional passage of the BCRA. ${ }^{104}$

Recognizing the distinction between issue advocacy generally and "genuine" or "pure" issue advocacy, the dissent echoed many of the sentiments expressed by Justice Scalia - a rare agreement between the two polar opposites - in its attack on the principal opinion. The dissent first described issue advocacy in its general usage as "an advertisement on a political subject urging the reader or listener to let a politician know what he thinks, but containing no magic words telling the recipient to vote for or against anyone."105 General usage of the term "issue advocacy" thus encompasses both sham issue ads and genuine issue ads, reflecting the simple magic words dividing line developed in Buckley. ${ }^{106}$

Seizing on the principal opinion's apparent disregard for the distinction between issue advocacy generally and its (much) smaller subpart of pure issue advocacy, the dissent explained the effective overruling of McConnell and, perhaps, even Buckley:

The principal opinion... simply inverts what we said in McConnell. While we left open the possibility of a "genuine" or "pure" issue ad that might not be open to regulation under [BCRA] $\S 203$, we meant that an issue ad without campaign advocacy could escape the restriction. The implication of the adjectives "genuine" and "pure" is unmistakable: if an ad is reasonably understood as going beyond a discussion of issues (that is, if it can be understood as electoral advocacy), then by definition it is not "genuine" or "pure." But the principal opinion inexplicably wrings the opposite conclusion from those words: if an ad is susceptible to any "reasonable interpretation other than as an appeal to vote for or against a specific candidate," then it must be a "pure" or "genuine" issue ad. This stands McConnell on its head, and on this reasoning it is possible that even some ads with magic words could not be regulated.

Under the principal opinion's test, the campaigning process is likely to revert back to the two tiers that the BCRA and McConnell sought to change: (1) a "tightly regulated and controlled" tier of candidates and political parties; and (2) a tier of interest groups that operate "under the

104. See id. at 504-07.

105. Id. at 515 .

106. See id. at $515-16$.

107. Id. at 526-27 (citations omitted). 
guise of "issue advocacy," but quite clearly focus on election activities, which lie beyond accountability. ${ }^{108}$

With the retirement of Justice Souter, the number of Justices virtually certain to continue this line of reasoning and support regulation in Citizens United is reduced to three. It is likely, however, that Justice Sotomayor will join this camp. ${ }^{109}$ With this contextual setting in place, this Comment proceeds to analyze areas of campaign finance law that should be considered in Citizens United and later cases.

\section{Citizens United and the Future of Campaign Finance Law}

No reasonable person should dispute that pure issue advocacy, as defined below, should be free from regulation. Likewise, it is clear that the magic words standard of Buckley permits electoral advocacy to escape regulation under the guise of issue advocacy. Disagreement manifests over the extent to which regulation should exist regarding ads that contain both candidate advocacy and issue advocacy, and whether either type exists in a particular ad in the first place. Nevertheless, all should also agree that individuals, corporations, and unions should play by a fair set of rules in campaign finance. The problem arises in determining what is "fair" when balancing competing interests of "freedom of speech and association, political equality, electoral competitiveness, and controlling the undue influence of money on the political process." 110 To help develop a fair set of rules, this section clearly defines the bounds of advocacy below.

1. Building Blocks: Defining Pure, Express, and Mixed (So-Called Issue) Advocacy

It has been argued that "Buckley drew a constitutionally mandated line between express advocacy and so-called issue advocacy, and that speakers possess an inviolable First Amendment right to engage in the latter category of speech."111 However, the Court rejected such a contention, explaining that Buckley's "express advocacy limitation, in both the expenditure and the disclosure contexts, was the product of statutory interpretation rather than a constitutional command." ${ }^{112}$ The

\footnotetext{
108. $I d$. at $518 \mathrm{n} .10$.

109. See Liptak, supra note 6.

110. Briffault, supra note 8, at 140.

111. McConnell v. FEC, 540 U.S. 93, 190 (2003).

112. Id. at 191-92.
} 
Court found that express advocacy and so-called issue advocacy were "functionally identical in important respects" and that "the presence or absence of magic words cannot meaningfully distinguish electioneering speech from a true issue ad." ${ }^{113}$ Moreover, the Court has held that corporate candidate advocacy - both express advocacy and the functional equivalent - can be regulated. ${ }^{114}$ Thus, deciphering the various types of advocacy becomes crucial because a statute that is "neither vague nor overbroad" can constitutionally regulate so-called issue advocacy. ${ }^{115}$ Advocacy can be fairly divided into three categories: (1) pure issue advocacy; (2) express candidate advocacy; and (3) the functional equivalent of express advocacy, or mixed (so-called issue) advocacy, which is comprised of both sham issue ads and genuine issue ads that also advocate for or against a candidate. ${ }^{116}$

\section{a. Pure Issue Advocacy}

McConnell left open the possibility that "genuine" or "pure" issue ads may escape the regulation of BCRA $\S 203 .{ }^{117}$ WRTL II, with its test, sought to remove any doubt, excluding issue advocacy from its definition of the functional equivalent of express advocacy, thereby protecting genuine issue advocacy-and probably sham issue advocacy-from regulation. Although the terms "genuine" and "pure" are often used interchangeably, they are not one and the same, and the difference is significant in successfully regulating campaign finance ads.

Before analyzing this distinction, it is helpful to define "issue advocacy" generally. An "issue" is "a point, matter, or dispute, the decision of which is of special or public importance."118 Thus, an issue can be either electoral (candidate oriented), such as a candidate's qualifications or voting record, or political (issue oriented), such as taxes, health care, or abortion. ${ }^{119}$ "Advocacy" is "the act of pleading for,

\footnotetext{
113. Id. at 126,193 .

114. FEC v. Wis. Right to Life, Inc. (WRTL II), 551 U.S. 449, 481 (2007) (citing Austin v. Mich. Chamber of Commerce, 494 U.S. 652, 659 (1990) (upholding regulation of corporate campaign speech); McConnell, 540 U.S. at 206 (upholding regulation of the functional equivalent of corporate campaign speech)).

115. McConnell, 540 U.S. at 192.

116. See also Krasno \& Sorauf, supra note 38, at 154 (separating advocacy communications into three types: candidate ads, candidate-oriented issue ads, and pure issue ads).

117. McConnell, 540 U.S. at 206 n. 88 .

118. RANDOM HOUSE UNABRIDGED DiCTIONARY 1015 (2d ed. 1993).

119. This Comment recognizes that the term "issue" also encompasses matters outside electoral or political issues, such as selecting a new chancellor for my beloved alma mater, but this is irrelevant to campaign finance law.
} 
supporting, or recommending; active espousal."120 Thus, "issue advocacy" broadly encompasses the acts of pleading for or against any of the issues identified above, both electoral and political. Consequently, the terms "issue advocacy" and "so-called issue advocacy" do not meaningfully separate electoral advocacy from political advocacy, which is imperative to develop a standard that comports with the different constitutional commands for each type as interpreted by the Court in Buckley and later cases. For the purposes of clarity and to comport with popular usage, this Comment will use the term "issue" to refer to political issues only and will not consider electoral matters (that promote, attack, support, or oppose a candidate) to be "issues."

In campaign finance jurisprudence, "genuine issue advocacy" is generally used to refer to ads that focus on issues other than electoral issues and refrain from discreetly attacking or promoting a candidate. This general usage, however, is not necessarily accurate. "Genuine" is defined to mean: "(Of a thing) authentic or real; something that has the quality of what it is purported to be or to have." ${ }^{\prime 21}$ Thus, genuine issue advocacy encompasses any ad that authentically pleads for or against an issue. It is possible that an organization may want to genuinely advocate for both an issue and a candidate in the same message. While this ad is certainly genuine and labeling this ad a sham would be inaccurate, the ad should nevertheless be regulated because it engages in electoral advocacy. This ad is perhaps better termed mixed advocacy, or the functional equivalent of express advocacy, because it engages in both genuine candidate advocacy and genuine issue advocacy.

Thus, while genuine issue ads should sometimes be regulated, there is a category of ads that should never be regulated: pure issue advocacy, or perhaps more accurately, pure, genuine issue advocacy. "Pure" is defined as "free from anything of a different, inferior, or contaminating kind; free from extraneous matter[;] . . being that and nothing else."122 Hence, pure issue advocacy is the act of pleading for a point or matter of public importance, focusing only on that particular point or matter and nothing else. Thus, if an ad leaves the reasonable bounds of advocating that particular issue, or includes other information of a different or contaminating kind, it is no longer pure issue advocacy. Under this definition, a pure issue ad is not necessarily prohibited from mentioning

120. RANDOM HOUSE UNABRIDGED DictionaRY 30 (2d ed. 1993).

121. BLACK'S LAW DiCTIONARY 708 (8th ed. 2004).

122. RANDOM House UnABRIDGED Dictionary 1569 (2d ed. 1993). 
a federal candidate or officeholder, which is why BCRA $\S 203$, as examined under McConnell, was problematic.

Chief Justice Roberts provides further guidance into the essential attributes of genuine issue advocacy: "[It] conveys information and educates. An issue ad's impact on an election, if it exists at all, will come only after the voters hear the information and choose-uninvited by the ad - to factor it into their voting decisions." 123 Thus, under Chief Justice Roberts's analysis of issue advocacy, there is no reason to shield ads that contain any degree of candidate advocacy, explicitly or implicitly, because they go beyond providing information and educating, and necessarily invite voters "to factor it into their voting decisions.". This conclusion is consistent with McConnell and compatible with Buckley and the Constitution: pure issue advocacy is never regulated and ads with any candidate advocacy, whether express or not, are always regulated. Thus, the key is developing a standard to determine when an ad engages in candidate advocacy.

\section{b. Express Candidate Advocacy}

Under virtually all standards, the Court has upheld the regulation of express candidate advocacy. To avoid a chilling effect on free speech, the Court largely explained this definition to mean "communications containing express words of advocacy of election or defeat, such as 'vote for,' 'elect,' 'support,' 'cast your ballot for,' 'Smith for Congress,' 'vote against,' 'defeat,' [or] 'reject.", 125 However, the term is not necessarily so restricted. "Express" means "clearly indicated; distinctly stated; definite; explicit; plain." 126 A "candidate" is "a person who seeks an office." 127 Thus, express candidate advocacy refers to the act of supporting or opposing, in a clear and distinct manner, a person for office. Although express candidate advocacy may use issue advocacythe act of supporting a point or matter of public importance - to enhance its express candidate advocacy, the primary goal of the ad is to promote or attack a candidate.

It is not necessary to use the magic words, or even words at all, to engage in express candidate advocacy. Indeed, visual images, charts, graphs, or music can accomplish this goal. For instance, an ad featuring

123. FEC v. Wis. Right to Life, Inc. (WRTL II), 551 U.S. 449, 470 (2007).

124. Id.

125. Buckley v. Valeo, 424 U.S. 1, 44 n.52 (1976).

126. RANDOM HOUSE UNABRIDGED DiCTIONARY 683 (2d ed. 1993).

127. Id. at 304 . 
a photo of a candidate with a large " $\mathrm{X}$ " drawn over it could hardly be defended as anything other than express candidate advocacy. Ads that seek to avoid regulation under the guise of issue advocacy would likely avoid these extreme measures, so exploring this category further is unnecessary.

c. The Functional Equivalent of Express Advocacy: Mixed (So-Called Issue) Advocacy

While it is tempting to label this category sham issue advocacy, and although all ads in this category should face regulation, it is more accurately labeled mixed advocacy with two subparts. One subpart, as explored earlier, is comprised of ads that genuinely advocate for or against both an issue and a candidate. ${ }^{128}$ The second subpart, which is more common, involves a corporation that seeks to use issue advocacy as a guise to avoid regulation while engaging in candidate advocacy, hence, a sham. Sham ads purport to focus on issues and avoid the use of clearly prohibited magic words, yet promote, attack, support, or oppose a candidate. Often, this area of advocacy is termed simply "issue advocacy." Reflecting the unclear nature of this area, the line between issue advocacy and candidate advocacy has been described as "a line in the sand drawn on a windy day.... It is foolish to believe there is any practical difference between issue advocacy and advocacy of a political candidate."129 Notwithstanding this assertion, there are meaningful differences and a standard can be developed such that the distinction does not "dissolve in practical application."

The Court has upheld the regulation of the "functional equivalent of express advocacy."131 "Functional" is defined as: "of or pertaining to a function or functions; having or serving a utilitarian purpose; capable of serving the purpose for which it was designed."132 "Equivalent" means "equal in value, measure, force, effect, significance, etc."133 Hence, the "functional equivalent of express advocacy" can be stated as the act of supporting or opposing a person for office, not in clear and distinct

\footnotetext{
128. See supra Part III.C.1.a.

129. McConnell v. FEC, 540 U.S. 93, 128 n.16 (2003) (citation omitted).

130. See id. at 327 (Kennedy, J., concurring in the judgment in part and dissenting in part with respect to BCRA Titles I and II).

131. FEC v. Wis. Right to Life, Inc. (WRTL II), 551 U.S. 449, 482 (2007) (citing McConnell, 440 U.S. at 206).

132. RANDOM HOUSE UNABRIDGED DiCTIONARY 775 (2d ed. 1993).

133. Id. at 657 .
} 
terms, but with any message that serves that purpose with roughly equal effect or force.

Notwithstanding the difficulty of separating issue advocacy from candidate advocacy, this Comment asserts that (1) a court can reasonably determine when these ads purely advocate for or against an issue or issues without promoting, attacking, supporting, or opposing a candidate; and, consequently, (2) ads that do not purely advocate an issue or issues should be interpreted as the functional equivalent of express advocacy and regulated. "Unusually important interests" justify the regulation of corporate campaign-related speech. ${ }^{134}$ These interests justify the regulation of any corporate speech that occurs outside of a PAC and goes beyond pure issue advocacy as defined herein because all ads that cannot be distinguished as pure issue advocacy necessarily involve some degree of candidate advocacy by promoting, attacking, supporting, or opposing a candidate. Pure issue advocacy is the only type of advocacy that avoids the corrupting potential of candidate advocacy in all its forms. Moreover, pure issue advocacy retains its full force and effect without a mere hint toward any candidate other than for contact purposes, and these appeals to the human consciousness often gain more persuasiveness or sympathy by omitting any reference to a candidate or election. After determining that only pure issue advocacy should be free from regulation, the trick becomes drawing a line-that does not "dissolve in practical application" "135 - to determine when an ad becomes the functional equivalent of express advocacy by promoting, attacking, supporting, or opposing a candidate.

\section{When Does an Ad Promote, Attack, Support, or Oppose a Candidate?}

In WRTL II, Justice Scalia used a Moroccan cartoonist to draw an analogy to American campaign finance law:

A Moroccan cartoonist once defended his criticism of the Moroccan monarch [which was a serious crime] as follows: "I'm not a revolutionary, I'm just defending freedom of speech .... I never said

134. McConnell, 540 U.S. at 206 n.88 (citing First Nat'l Bank of Boston v. Bellotti, 435 U.S. $765,788-89$ (1978)).

135. See id. at 327 (Kennedy, J., concurring in the judgment in part and dissenting in part with respect to BCRA Titles I and II). 
we had to change the king - no, no, no, no! But I said that some things the king is doing, I do not like. Is that a crime?"136

Accounting for the fact that the United States has elected representatives rather than a king, Justice Scalia answered that BCRA $\S 203$ makes it a crime if the speaker is a union or corporation and the representative is identified by name within a restricted period. ${ }^{137}$ Justice Scalia then used the analogy to explain that McConnell left open the possibility that the BCRA prohibition may be unconstitutional if the ad criticized "only the king's policies and not his tenure in office."138 Thus, the essential question: "Does attacking the king's position attack the king?" 139

If a corporation seeks to attack a policy (perhaps of the king), and not necessarily the king, then it does not matter if the king supports the policy for the purpose of attacking the policy. If a corporation truly attacks a policy on the merits of the policy, it is unnecessary to indicate or allude to the king's position on the policy. If listeners are moved by the merits of the policy, it may naturally lead them to inquire about the king's position or plead with the king to change his position (if they already knew it or once they learn it). Accordingly, the corporation should be permitted to tell the listeners who their king is and how he can be contacted. The corporation could even provide a link for the listener that provides more information about the policy or begins to explain that the policy belongs to the king. But if in the initial announcement, the corporation must allude to the fact that the policy actually belongs to the king, then it is not the policy or its merits that are under attack, but the king himself. The discussion moves from changing the policy to changing the king in order to get a different policy. The merits of the policy get contaminated with personal attributes of the king. To accomplish this mixed discussion in an initial announcement, the corporation should be forced to use a PAC, because whether it intends to or not, the corporation effectively attacks the king.

Therefore, in response to Justice Scalia's question-“[d]oes attacking the king's [policy] attack the king?"140 - the answer is yes, if the announcement alludes to the fact that the policy belongs to the king

\footnotetext{
136. WRTL II, 551 U.S. at 483 (Scalia, J., concurring in part and concurring in the judgment) (citation omitted).

137. Id.

138. Id.

139. Id. at 493 .

140. Id.
} 
(without first attacking the merits of the policy on the merits alone). Now, certainly some listeners will already know the policy belongs to the king (as certainly as many will not), but this does not affect the analysis. The intent of the speaker is irrelevant, and the effect on the listener of alluding to the candidate's position or other qualities will always be to infuse a discussion on the merits of a policy with contaminating candidate discussion, which necessarily leads to promoting or attacking a candidate.

Thus, to draw from the analogy, by replacing "policy" with "issue," "king" with "named candidate or officeholder," and "announcement" with "broadcast advertisement," this Comment asserts that a standard can be developed which permits a corporation to attack a candidate's position on an issue without attributing the underlying position to the candidate, and thus without attacking the candidate. This analogy provides an effective solution for distinguishing when and how it is appropriate to mention a candidate or officeholder in an ad from when and how an ad crosses the line into the functional equivalent of express advocacy by effectively engaging in both candidate and issue advocacy.

To help summarize the analogy, a court should look to clear criteria to determine whether an ad promotes, attacks, supports, or opposes a candidate. Pure issue advocacy promotes or attacks a policy itself; thus, an unregulated ad should not attack a candidate by discussing his personal characteristics nor attribute the policy under attack to the candidate. It should focus purely on the merits of the issue. The ad could recommend contacting the representative and encouraging him to take action on the policy, but it cannot hint at the actual position of the candidate or his attributes, which would contaminate the ad. To apply the reasoning of Chief Justice Roberts, the ad would no longer only inform and educate, but also impermissibly invite voters to factor it into their voting decisions. ${ }^{141}$ If a viewer of the ad is persuasively moved by the merits of the issue, it should naturally lead him to inquire into the position of a candidate or take other action, which is not only acceptable, but one of the underlying goals of pure issue advocacy. Such inquiry promotes the "uninhibited, robust, and wide-open" discussion of public issues vital to our democracy. ${ }^{142}$ But the pure issue ad should not suggest or allude to the position of the candidate or his personal attributes in any manner.

141. See supra notes $123-24$ and accompanying text.

142. See WRTL II, 551 U.S. at 467 (quoting Buckley v. Valeo, 424 U.S. 1, 14 (1976)). 
While it should be relatively easy to determine when an ad mentions a candidate for any purpose other than to identify him for viewers and provide his contact information, several actions by an ad should qualify as alluding to the candidate's position or personal attributes. In addition to referring directly to a candidate's position, a reference to his prior positions or votes would immediately disqualify the ad as pure issue advocacy. Although perhaps more disguised, an ad would also cross the line by identifying a group (perhaps a political party, other candidates, family, friends, contributors, or supporters) and insinuating that the candidate shares the same beliefs as the group. Additionally, an ad would not be pure if it identified other issues in which the candidate had been involved and attempted to attribute some connection to the issue at hand. Mentioning personal attributes of a candidate similarly contaminates an ad, whether it be religion, age, a hobby, or otherwise. Finally, an ad which uses a visual image to imply any of the above should likewise be regulated.

Before proceeding to develop a standard, it should be remembered that a corporation always has a PAC option available. ${ }^{143}$ If a corporation wishes to forgo this option, it can also use mixed advocacy by avoiding any reference to a candidate. If it feels the necessity to mention a candidate, it can do so only to identify him as the elected representative, provide his contact information, and encourage listeners to contact him. But it cannot, whether directly or indirectly, allude to the candidate's position on an issue or anything else about the candidate. In effect, the corporation can attack the candidate's policy without a viewer necessarily knowing that it is the candidate's policy, and because the viewer does not necessarily know the candidate's position, the ad cannot reasonably be deemed to promote, attack, support, or oppose the candidate. After thoroughly examining when a so-called issue ad crosses the line, the trick becomes articulating a standard that protects pure issue advocacy, but regulates the functional equivalent of express advocacy while avoiding constitutional vagueness and overbreadth concerns.

3. The Means to an End: A Standard That Protects Pure Issue Advocacy and Only Pure Issue Advocacy

After establishing that only pure issue advocacy should be fully protected from regulation and clearly defining its bounds, and establishing a clear line to determine when an ad becomes the functional 
equivalent of express advocacy by promoting, attacking, supporting, or opposing a candidate, the task becomes developing a standard to meet the end goal. Fortunately, several sources provide guidance: the BCRA's primary and fallback definitions of electioneering communication, the WRTL II district court's five-part test, and the WRTL II principal opinion's test and corresponding analysis by Chief Justice Roberts and Justice Scalia.

Perhaps the best starting point is the WRTL II principal opinion, which sets guidelines for a proper standard to use in as-applied challenges to BCRA $\S 203$. The Chief Justice declared that any test

must be objective, focusing on the substance of the communication rather than amorphous considerations of intent and effect. It must entail minimal if any discovery, to allow parties to resolve disputes quickly without chilling speech through the threat of burdensome litigation. And it must eschew "the open-ended rough-and-tumble of factors," which "invites complex argument in a trial court and a virtually inevitable appeal."

Applying these criteria, the standard developed herein looks promising. Under the standard, the intent of the corporation in airing an ad is irrelevant, and the effect of all ads which do not meet the protected class of pure issue advocacy necessarily affect the listeners such that they are the functional equivalent of express advocacy. ${ }^{145}$ Additionally, the standard requires minimal, if any, discovery; analysis is restricted to the objective content of the ad. Finally, the standard does not use openended factors like the WRTL II district court's test below. ${ }^{146}$

Before developing a standard, it is also helpful to examine where other standards went awry. The BCRA's primary definition of "electioneering communication" is perhaps the easiest example. ${ }^{147}$ To avoid vagueness concerns, it made no attempt to evaluate the content of the ad; rather, it restricted every ad that met the definition. ${ }^{148}$ As examined earlier, it was thus overbroad because some ads which met the definition were nevertheless purely issue ads. ${ }^{149}$ While Buckley's magic words test is likewise clear and easy to apply, it is equally problematic because it lets ads escape regulation that quite clearly engage in

\footnotetext{
144. Id. at 469 (citations omitted).

145. See supra Part III.C.2.

146. See infra notes $152-53$ and accompanying text.

147. See supra note 39 and accompanying text.

148. See supra notes $44-45$ and accompanying text.

149. See supra Part III.B.1.
} 
candidate advocacy, although under the guise of an issue. Thus, any effective standard must balance constitutional concerns with practical application.

The WRTL II principal opinion's test moves in the correct direction: "a court should find that an ad is the functional equivalent of express advocacy only if the ad is susceptible of no reasonable interpretation other than as an appeal to vote for or against a specific candidate."150 However, it fails to provide any guiding principles for determining "reasonableness." The wording is also problematic because an ad should be regulated if it has any reasonable interpretation as an appeal to vote for or against a candidate, thereby crossing the line into mixed advocacy, rather than escaping regulation by creating other reasonable interpretations. ${ }^{151}$

As Justice Scalia accurately determined, the five-factor test developed by the district court in WRTL II raised enough vagueness concerns that it was unacceptable to adopt. ${ }^{152}$ However, analysis of the factors helps improve the standard here. To determine whether an ad was express advocacy or its functional equivalent, the district court looked within the four corners of the ad to examine whether it:

(1) describes a legislative issue that is either currently the subject of legislative scrutiny or likely to be the subject of such scrutiny in the near future; (2) refers to the prior voting record or current position of the named candidate on the issue described; (3) exhorts the listener to do anything other than contact the candidate about the described issue;

(4) promotes, attacks, supports, or opposes the named candidate; and (5) refers to the upcoming election, candidacy, and/or political party of the candidate.

The first factor should not be considered because it is irrelevant to whether an ad engages in pure issue advocacy. The second factor, as explored earlier, is helpful in determining when a so-called issue ad crosses the line into the functional equivalent of express advocacy. ${ }^{154}$ Factor three is problematic because a pure issue ad can genuinely exhort the viewer to do something other than contact the candidate. For example, encouraging a listener to pursue a website link to learn more about the issue should be permissible. Of course, in referring to the link,

\footnotetext{
150. FEC v. Wis. Right to Life, Inc. (WRTL II), 551 U.S. 449, 469-70 (2007).

151. See supra Part III.B.1.

152. See WRTL II, 551 U.S. at 492 (Scalia, J., concurring in part and concurring in the judgment).

153. Wis. Right to Life, Inc. v. FEC, 466 F. Supp. 2d 195, 207 (D.D.C. 2006)

154. See supra Part III.C.2.
} 
the ad cannot allude to the candidate or his position on the issue. The fourth and fifth factors help to determine how an ad may attempt to allude to a candidate's position or personal attributes, as analyzed earlier. ${ }^{155}$

While the BCRA's primary definition of electioneering communication may fail amid overbreadth concerns, the fallback definition presents a workable standard to avoid both vagueness and overbreadth concerns:

"[E]lectioneering communication" means any broadcast, cable, or satellite communication which promotes or supports a candidate for [federal] office, or attacks or opposes a candidate for that office (regardless of whether the communication expressly advocates a vote for or against a candidate) and which also is suggestive of no plausible meaning other than an exhortation to vote for or against a specific candidate. $^{156}$

To avoid vagueness concerns, as identified by Justice Scalia, however, it may need clearer guidelines. ${ }^{157}$ Additionally, as with the WRTL II principal opinion's test, the key is not whether an ad has any plausible meaning other than "as an exhortation to vote for or against a candidate," but whether it has any reasonable interpretation to invite a voter to factor it into his decision. ${ }^{158}$

Synthesizing the analysis conducted throughout this Comment, a standard can now be developed that should avoid vagueness and overbreadth constitutional concerns, regulate the functional equivalent of express advocacy (or mixed ads), and protect pure issue advocacy. A broadcast advertisement should be prohibited if it: (1) refers to a clearly identifiable federal candidate, whether by name, visual image, or otherwise; and (2) promotes, attacks, supports, or opposes the identified candidate (regardless of whether the communication expressly advocates a vote for or against the candidate) by alluding to the position of the candidate on any issue or to the personal attributes of the candidate. Using this standard, in the context of the analysis provided throughout this Comment, may sufficiently appease both sides of the debate (at least partially) by alleviating First Amendment concerns and protecting pure

155. See supra Part III.C.2.

156. Bipartisan Campaign Reform Act of 2002, Pub. L. No. 107-155, § 201(f)(3)(A)(ii), 116 Stat. 81,89 (codified at 2 U.S.C. $\S 434(f)(3)(A)(i i)$ ).

157. See WRTL II, 551 U.S. at 493 (Scalia, J., concurring in part and concurring in the judgment).

158. See supra Part III.B.1. 
issue advocacy, while also implementing the will of Congress to eradicate sham issue advocacy.

\section{Justifying "Electioneering Communication" in the Disclosure} Context

The BCRA uses the same definition of "electioneering communication" for expanding disclosure requirements in BCRA § 201 as it does for extending the prohibition on corporate spending in BCRA $\S 203 .{ }^{159}$ While the constitutionality of the term as used in BCRA $\S 203$ appears in jeopardy, this Comment asserts that additional governmental interests justify its use in the disclosure context.

Citizens United challenged the BCRA disclosure provisions as unconstitutional intrusions that deny the anonymity of donors and require the administrative costs of collecting and reporting the information. ${ }^{160}$ However, as the district court explained, "the Supreme Court has written approvingly of disclosure provisions triggered by political speech even though the speech itself was constitutionally protected under the First Amendment." 161

At least three governmental interests, as identified in Buckley, justify the use of the BCRA's broad electioneering communication standard in the disclosure context. First, preventing corruption and the appearance thereof justifies the broad disclosure requirements in BCRA $\S 201 .^{162}$ Second, providing the electorate with information justifies the requirements. ${ }^{163}$ With the disclosed information, voters can identify the source of advertising money to better evaluate the content of the ad. ${ }^{164}$ Additionally,

[i]t allows voters to place each candidate in the political spectrum more precisely than is often possible solely on the basis of party labels and campaign speeches. The sources of a candidate's financial support also alert the voter to the interests to which a candidate is most likely to be

159. See Bipartisan Campaign Reform Act $\S \S 201(\mathrm{f})(3), 203(\mathrm{c})$ (codified at 2 U.S.C. $\S \S$ 434(f)(3), 441b(c)).

160. Citizens United v. FEC, 530 F. Supp. 2d 274, 280 (D.D.C. 2008).

161. Id. at 281 (citing FEC v. Mass. Citizens for Life, 479 U.S. 238, 259-62 (1986) (striking down a prohibition and declaring that the newly permitted speech was nonetheless subject to the disclosure requirements))

162. See Buckley v. Valeo, 424 U.S. 1, 67 (1976).

163. See id. at 66-67.

164. See id. 
responsive and thus facilitate predictions of future performance in office.

Third, the disclosure requirements can be justified as necessary for collecting data to enforce other substantive provisions of the BCRA. ${ }^{166}$

While public disclosure may deter some individuals who might otherwise contribute, these competing interests should nevertheless justify the reporting requirements, as the Court overwhelmingly held in McConnell. ${ }^{167}$ As the Court explained, the broader disclosure requirements of BCRA $\S 201$ require "'organizations to reveal their identities so that the public is able to identify the source of the funding behind broadcast advertisements influencing certain elections." "168 Narrowing the disclosure requirements would decrease the ability of citizens to assess the credibility of advertisements and allow organizations to run their so-called issue ads while "hiding behind dubious and misleading names." 169 Moreover, "disclosure requirements are constitutional because they 'do not prevent anyone from speaking. ", 170

In summary, while WRTL II narrowed the scope of what could be regulated as an electioneering communication and Citizens United may continue deregulation, it does not necessarily follow that the term should likewise be narrowed in the disclosure context. ${ }^{171}$ Rather, the interests identified above should justify broad use of the term for disclosure.

\section{CONCLUSION}

As the Court considers Citizens United, it is helpful to analyze how the standard developed in this Comment would affect the ads in both WRTL II and Citizens United. Applying the proposed standard, it would reach the same result as the WRTL II Court in permitting Wisconsin Right to Life, Inc., to air all three ads. Although all three ads mention a

\footnotetext{
165. Id. at 67.

166. See id. at 67-68 (stating "disclosure requirements are an essential means of gathering the data necessary to detect violations of [] contribution limitations").

167. See McConnell v. FEC, 540 U.S. 93, 201-02 (2003).

168. Id. at 196 (quoting the district court's opinion).

169. See id. at 197 (quoting the district court's opinion); see also id. at 128, $128 \mathrm{n} .23$ (illustrating various misleading names).

170. Id. at 201 .

171. See also Briffault, supra note 8, at 131-33 (stating "it is quite possible that the Constitution will be held to permit one application of 'electioneering communication' for one set of regulations, but a different application of the very same term for a different set of regulations").
} 
federal candidate, they do not allude to the candidate's position on an issue or his attributes. ${ }^{172}$ Rather, they merely urge the listener to contact the candidate and encourage him to act in a certain manner, notwithstanding that listeners may already know his position on the issue. ${ }^{173}$ As explored earlier, these ads meet the criteria of pure issue ads and should be protected from regulation.

Applying this standard in Citizens United, the Court would reach the same conclusion as the district court that all three ads should be prohibited. The ads "Wait" and "Pants" allude to the personal attributes of the candidate and do not even mention, let alone discuss, a public issue. ${ }^{174}$ The ad "Questions" alludes to both the candidate's personal attributes ("Who is Hillary Clinton?"; "[s]he's continually trying to redefine herself"; and "Hillary's got an agenda") and her position on an issue (the form of government that is appropriate for America: "Hillary is the closest thing we have in America to a European socialist"). ${ }^{175}$

By returning to many of the principles of the McConnell decision and regulating sham issue advocacy, the proposed standard would likely garner the support of all three remaining Justices of the WRTL II dissent. Additionally, although Justice Sotomayor has yet to write an opinion on this subject, many believe she will also champion deference to Congress in this area. ${ }^{176}$ By avoiding a query into the intent and effect of the ad, and eschewing open-ended factors, the standard could also gain the endorsement of Chief Justice Roberts or Justice Alito. Even Justices Scalia, Kennedy, and Thomas, despite their well-known tendencies to vote against such regulations, may be sufficiently appeased if the criteria developed in the standard and corresponding analysis is clear enough to avoid a chilling effect on the freedom of speech and permit "uninhibited, robust, and wide-open" discussion of public issues. ${ }^{177}$

In any event, the standard attempts to offer a common sense solution that protects that which truly should not be regulated: pure issue advocacy. If the Court seeks to protect all so-called issue advocacyboth sham and genuine-perhaps the proposed standard and corresponding analysis will assist in the writing of future legislation. However, if five Justices seek to protect the virtues of pure, genuine

\footnotetext{
172. See FEC v. Wis. Right to Life, Inc. (WRTL II), 551 U.S. 449, 458-59 (2007) (providing transcripts of the ads "Wedding," "Loan," and "Waiting").

173. See id.

174. See Citizens United v. FEC, 530 F. Supp. $2 d$ 274, 276 nn.2-3 (D.D.C. 2008).

175. See id. at 276 n. 4 .

176. See Liptak, supra note 6.

177. See WRTL II, 551 U.S. at 467.
} 
issue advocacy, while ensuring that corporations and unions play by a fair set of rules, then the proposed standard should effectively implement the fallback definition as used in BCRA $\S 203$ to accomplish the goals of Congress. Should the Court strike down the prohibitions in BCRA $\S 203$, it should nevertheless uphold increased disclosure requirements to permit Americans to more accurately assess the credibility of the countless ads that air shortly before elections.

In closing, the attitude of the American people in the 2008 elections suggests that the concerns about corruption identified over a century ago have not subsided. In selecting the major presidential nominees, thenSenator Barack Obama and Senator John McCain, voters picked two candidates who championed the limitation of special interests, including corporate money, in elections and the political process generally. Moreover, voters nationwide expressed a genuine interest in public issues and substance, while attacks on candidates, including negative or misleading advertising, were generally disfavored by the public. As campaign finance law continues to evolve, this Comment should provide helpful guidance for Congress and the Court to improve the rules under which individuals, corporations, and unions may engage in political and electoral advocacy by implementing the will of the American people and closing the loophole for sham issue advocacy, while also protecting fundamental First Amendment rights and pure issue advocacy. 